\title{
Communication of the Anterior Branch of the Great Auricular Nerve with the Cervical Branch of Facial Nerve and its Variant Nerve Endings Deep in the Parotid Gland
}

\author{
Comunicación del Ramo Anterior del Nervio Auricular Mayor con el Ramo Cervical del Nervio \\ Facial y sus Terminaciones Nerviosas Profundas Variantes en la Glándula Parótida
}

"Srinivasa Rao Sirasanagandla; "Satheesha Nayak B.; "*k Kumar M. R. Bhat \& "Swamy Ravindra S.

RAO, S. S.; NAYAK, B. S.; BHAT, K. M. R. \& RAVINDRA, S. S. Communication of the anterior branch of the great auricular nerve with the cervical branch of facial nerve and its variant nerve endings deep in the parotid gland. Int. J. Morphol., 30(3):840-842, 2012.

SUMMARY: The communications between the branches of cervical plexus and cervical branch of facial nerve are common and are well known. However, this communication usually occurs between the transverse cervical nerve and cervical branch of facial nerve. During routine dissection classes for the Medical undergraduate students, we came across an anatomical variant of anterior division of great auricular nerve. This variation was found in a 60-year-old male cadaver of South Indian origin and it was unilateral. The great auricular nerve arose from the loop of ventral rami of $\mathrm{C} 2$ and $\mathrm{C} 3$ spinal nerves and divided into anterior and posterior branches. The anterior branch ran obliquely upwards and forwards on the surface of the sternocleidomastoid muscle along with the external jugular vein towards the apex of parotid gland and divided into many branches. One of these branches gave a communicating branch to cervical branch of facial nerve outside the parotid gland. Nerve endings of the remaining branches were found to penetrate the interlobular septa and a few of them were seen deep in the gland along the ducts and near the vessels. The functional significance of anatomic variations of nerve endings in relation to ducts, thin vessels deep in the parotid gland, observed in the present case are yet to be evaluated.

KEY WORDS: Great auricular nerve; Cervical plexus; Communication; Facial nerve; Parotid gland.

\section{INTRODUCTION}

Ventral rami of upper four cervical spinal nerves form the cervical plexus, and supply some of the areas of skin on the head, neck and chest through its cutaneous branches. The plexus lies deep to the prevertebral fascia, and its superficial cutaneous branches, the lesser occipital, great auricular, transverse cervical and supraclavicular nerves pierce the fascia to supply the skin. Great auricular nerve (GAN) is the largest among the cutaneous branches of plexus. It arises from the second and third cervical rami and emerges on the surface of the sternocleidomastoid muscle by winding around its posterior border. Then it ascends on the muscle deep to platysma towards the apex of the parotid gland where it divides into anterior and posterior branches. Anterior branch is sensory to facial skin over the parotid gland. Posterior branch supplies the skin over the mastoid process, back of the auricle, lobule and a portion of the scalp.

\section{CASE REPORT}

During routine dissection classes to first year Medical students, we found an anatomical variation of anterior division of great auricular nerve, in the Department of Anatomy, Melaka Manipal Medical College, Manipal University, Manipal. The variation was observed in 60 yearold-male cadaver and it was Unilateral. The GAN arose from the loop of ventral rami of $\mathrm{C} 2$ and $\mathrm{C} 3$ spinal nerves and divided into anterior and posterior branches. The anterior branch ran obliquely upwards and forwards on the surface of the sternocleidomastoid muscle along with the external jugular vein. On the way, it divided into two branches. These branches further divided into many small branches close to the apex of parotid gland. One of these branches gave a communicating branch to cervical branch of facial nerve just outside the parotid gland. A few nerve endings of the remaining branches were found to penetrate the interlobular

\footnotetext{
* Department of Anatomy, Melaka Manipal Medical College, Manipal University, Madhav Nagar, Manipal, Karnataka, India. *"Department of Anatomy, Kasturba Medical College, Manipal University, Manipal, Karnataka, India.
} 


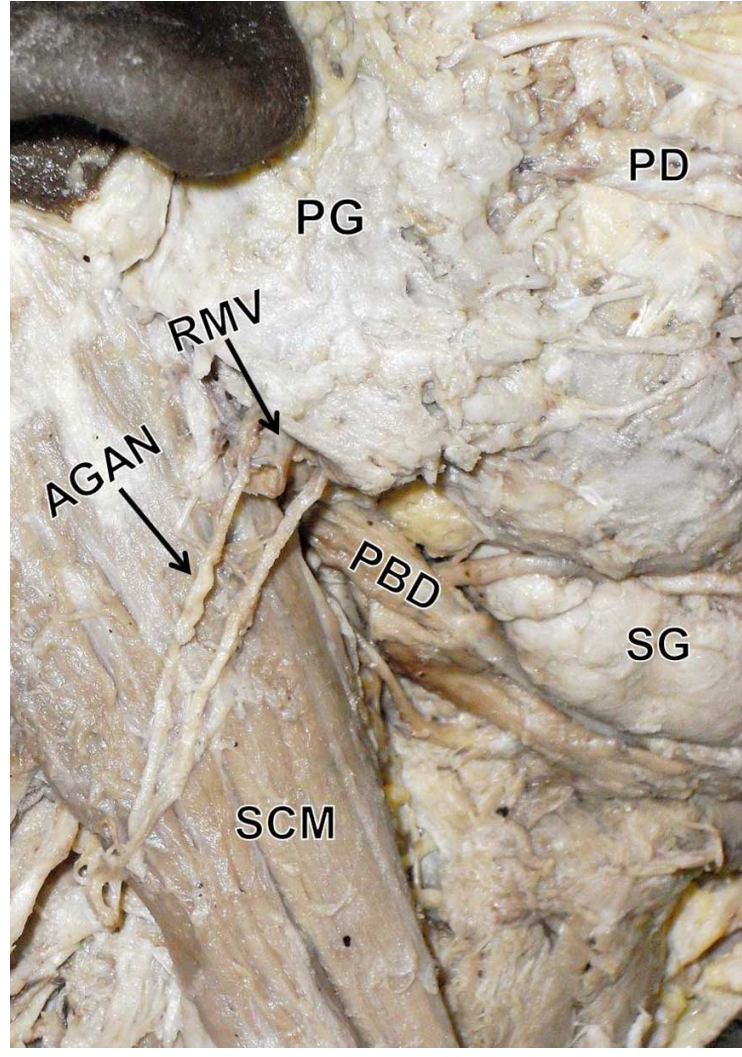

Fig. 1. Photograph showing the superficial dissection of neck and parotid region. AGAN: anterior division of great auricular nerve; SCM: sternocleidomastoid muscle; RMV: retromandibuar vein; PG: parotid gland; SG: submandibular gland; PBD: posterior belly of digastric muscle; PD: parotid duct.

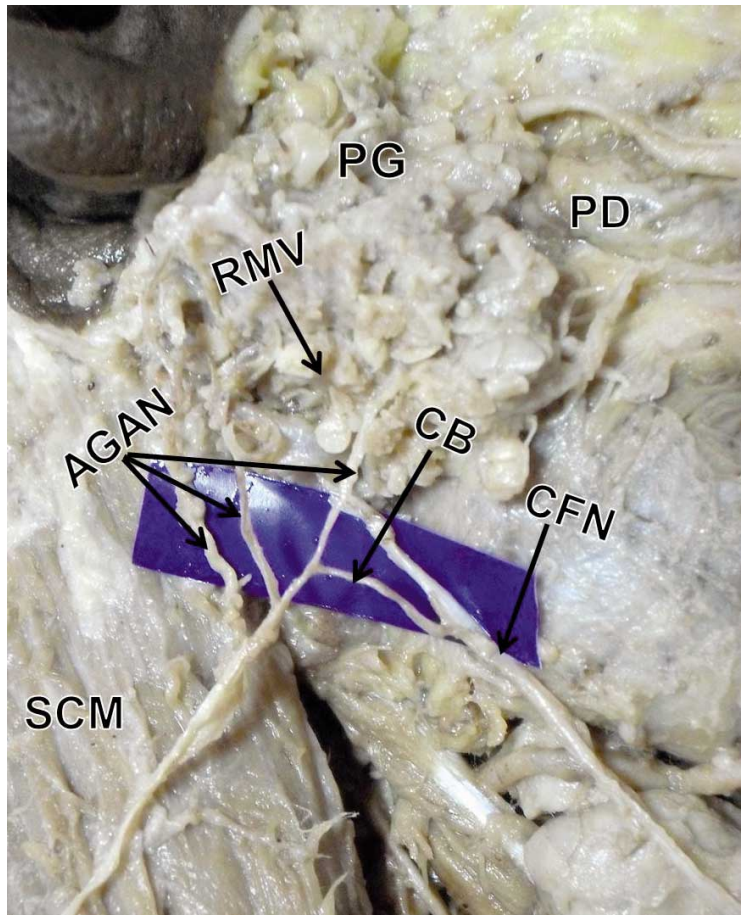

septa and a few of them were seen deep in the gland along ducts and near the vessels especially in relation to retromandibular vein (Figs. 1 and 2).

\section{DISCUSSION}

Cutaneous branches of cervical plexus usually communicate with the branches of facial nerve and are well known (Sinnatamby, 2006; Standring, 2008). These communications commonly occur between the transverse cervical nerve and cervical branches of facial nerve. Transverse cervical nerve divides into ascending and descending branches, the ascending branch forms plexus with the cervical branch, deep to platysma muscle in the submandibular region (Standring). In a recent study, this communication was found in 22 neck dissections (11 cadavers) and most of them were observed at the inferior border of submandibular gland (Domet et al., 2005). Communications between the cervical plexus and spinal accessory nerve are also well known and have been reported in the past (Soo et al., 1986; Kierner et al., 2000). Branches of cervical plexus rarely communicate with phrenic nerve (Loukas et al., 2006). In one of the earlier reports, a communication between the accessory nerve and the ansa cervicalis has been described (Khaki et al., 2006). The ansa cervicalis may even be replaced by a vagocervical plexus (Abu-Hijleh et al., 2005). A study on emergence of cutaneous nerves through the prevertebral fascia has found a close relation between the great auricular nerve and transverse cervical nerve (Kim et al., 2002). This anatomical variation was identified in 13 of 64 dissections.

Communications between the GAN and cranial nerves are well known. Standring described the GAN to divide into anterior and posterior branches. The anterior branch sends a small twig or several small twigs into the substance of the parotid gland and connects to the facial nerve. The posterior branch communicates with the auricular branch of the vagus nerve and also with the posterior auricular branch of the facial nerve. A rare communication between the anterior division of GAN and marginal mandibular branch of facial nerve, outside the parotid gland has been reported (Brennan et al., 2008). Brennan et al. (2010) identified this anatomical variation in 2 of 25 dissections. In the present case, we report an anatomical variant of communication of anterior division of great auricular nerve with cervical branch of facial nerve outside the parotid gland. Termination of endings of anterior branch of GAN along the ducts and vessels deep in the parotid gland is described as its anatomical variation. Zohar et al. (2002) studied

Fig. 2. Photograph showing the closer view of the variation. AGAN: anterior division of great auricular nerve; SCM: sternocleidomastoid muscle; $\mathrm{CB}$ : communicating branch; $\mathrm{CFN}$ : cervical branch of facial nerve; PG: parotid gland; PD: parotid duct; RMV: retromandibuar vein. 
the pathway of anterior division nerve endings in relation to parotid gland. In this study, nerve bundles were found to penetrate the interlobular septa in $13 \%$ cases and nerve bundles were seen deep in the gland close to small ducts and thin-walled blood vessels in $30 \%$ cases. Supporting the previous findings, in the present case we observed a few branches penetrating the interlobular septa and few of them running along the ducts and thin walled blood vessels (retromandibular vein) deep in the bland.
The clinical importance of this variation is that during neck surgeries, the stimulation of a communicating nerve of the cervical plexus might result in tense oblique ridges in the skin of neck due to the contraction of platysma, and could potentially cause the operating surgeon to think that it was a branch of the facial nerve. The functional significance of anatomic variations of nerve endings in relation to ducts, thin vessels deep in the parotid gland, observed in the present case are yet to be evaluated.

RAO, S. S.; NAYAK, B. S.; BATH, K. M. R. \& RAVINDRA, S. S. Comunicación del ramo anterior del nervio auricular mayor con el ramo cervical del nervio facial y sus terminaciones nerviosas profundas variantes en la glándula parótida. Int. J. Morphol., 30(3):840-842, 2012.

RESUMEN: Las comunicaciones entre los ramos del plexo cervical y ramo cervical del nervio facial son comunes y bien conocidos. Sin embargo, esta comunicación por lo general ocurre entre el nervio cervical transverso y el ramo cervical del nervio facial. Durante las clases de disección de rutina para los estudiantes de pregrado de medicina, nos encontramos con una variante anatómica de la división anterior del nervio auricular mayor, unilateral, en un cadáver de sexo masculino de 60 años, del Sur de la India. El nervio auricular mayor se originó desde el bucle de los ramos ventrales de los nervios espinales C2 y C3, y dividió en ramos anterior y posterior. El ramo anterior se dirigió oblicuamente hacia arriba y adelante sobre la superficie del músculo esternocleidomastoideo junto con la vena yugular externa hacia el ápice de la glándula parótida y se dividió en numerosos ramos terminales. Uno de estos ramos dió un ramo comunicante al ramo cervical del nervio facial fuera de la glándula parótida. Las terminaciones nerviosas de los ramos restantes penetraron en los septos interlobulares. Algunos de éstos se observaron profundos en la glándula a lo largo de los conductos y cerca de los vasos. La importancia funcional de las variaciones anatómicas de las terminaciones nerviosas en relación a los conductos y vasos finos profundos en la glándula parótida aquí observados aún no se han evaluado.

PALABRAS CLAVE: Nervio auricular; Plexo cervical: Comunicación; Nervio facial; Glándula parótida.

\section{REFERENCES}

Abu-Hijleh, M. F. Bilateral absence of ansa cervicalis replaced by vagocervical plexus: case report and literature review. Ann. Anat., 187(2):121-5, 2005.

Brennan, P. A.; Al Gholmy, M.; Ounnas, H.; Zaki, G. A.; Puxeddu, R. $\&$ Standring, S. Communication of the anterior branch of the great auricular nerve with the marginal mandibular nerve: A prospective study of 25 neck dissections. Br. J. Oral Maxillofac. Surg., 48(6):431-3, 2010.

Brennan, P. A.; Webb, R.; Kemidi, F.; Spratt, J. \& Standring, S. Great auricular communication with the marginal mandibular nerve - a previously unreported anatomical variant. Br. J. Oral Maxillofac. Surg., 46(6):492-3, 2008.

Domet, M. A.; Connor, N. P.; Heisey, D. M. \& Hartiq, G. K. Anastomoses between the cervical branch of the facial nerve and the transverse cervical cutaneous nerve. Am. J. Otolaryngol., 26(3):168-71, 2005.

Khaki, A. A.; Shokouhi, G.; Shoja, M. M.; Farahani, R. M.; Zarrintan, S.; Khaki, A.; Montazam, H.; Tanoomand, A. \& Tubbs, R. S. Ansa cervicalis as a variant of spinal accessory nerve plexus: a case report. Clin. Anat., 19(6):540-3, 2006.

Kierner, A. C.; Zelenka, I.; Heller, S. \& Burian, M. Surgical anatomy of the spinal accessory nerve and the trapezius branches of the cervical plexus. Arch. Surg., 135(12):1428-31, 2000.

Kim, H. J.; Koh, K. S.; Oh, C. S.; Hu, K. S.; Kang, J. W. \& Chung, I. $\mathrm{H}$. Emerging patterns of the cervical cutaneous nerves in Asians. Int. J. Oral Maxillofac. Surg., 31(1):53-6, 2002.
Loukas, M.; Kinsella, C. R. Jr.; Louis, R. G. Jr.; Gandhi, S. \& Curry, B. Surgical anatomy of the accessory phrenic nerve. Ann. Thorac. Surg., 82(5):1870-5, 2006.

Sinnatamby, C. S. Head and neck and spine. In: Sinnatamby, C. S. (Ed.). Last's Anatomy. 11th ed. Edinburgh, Churchill Livingstone, 2006, pp.345-7.

Soo, K. C.; Hamlyn, P. J.; Pegington, J. \& Westbury, G. Anatomy of the accessory nerve and its cervical contributions in the neck. Head Neck Surg., 9(2):111-5, 1986.

Standring, S. Neck. In: Standring S. (Ed.). Gray's Anatomy. 40 ${ }^{\text {th }}$ ed. Edinburgh, Churchill Livingstone, 2008, pp.435-6.

Zohar, Y.; Siegal, A.; Siegal, G.; Halpern, M.; Levy, B. \& Gal, R. The great auricular nerve; does it penetrate the parotid gland? An anatomical and microscopical study. J. Craniomaxillofac. Surg., 30(5):318-21, 2002.

Correspondence to:

Mr. Srinivasa Rao Sirasanagandla

Lecturer, Department of Anatomy

Melaka Manipal Medical College

Manipal University

Madhav Nagar, Manipal, Karnataka, 576104

INDIA

Email: seenaih.anat@gmail.com

Received: 21-01-2012

Accepted: 11-06-2012 